Dept. of Parasitology,

Fac. of Vet. Med., Alexandria Univ.

Head of Dept. Prof. Dr. Y.Z. Otify.

\title{
HYPODERMATOSIS AMONG ANIMALS FURNISHING MEAT PRODUCTION IN GREEN MOUNTAIN-LIBYA
}

(With 3 Tables \& 2 Plate \& 4 Fig.)

By

Y.Z. OTIFY and NADA K. MANSOUR*

(Received at 20/10/1994)

\section{المبيبوديرماتوسيس فه حيوانات الذتاج اللحورA بالجبل الأخضر اليبيــا}

يجيى غمتيفى حنمبا عندئور

فحم عدد •MA رأس من المـاعز والأبقار والأغنام بمنطقة الجبل الأخضر بليبيا فد الامابه

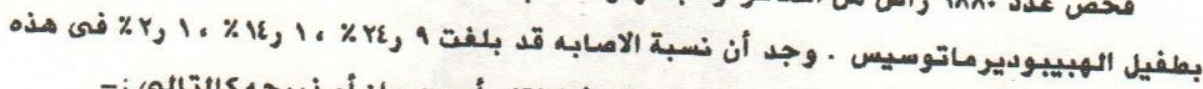

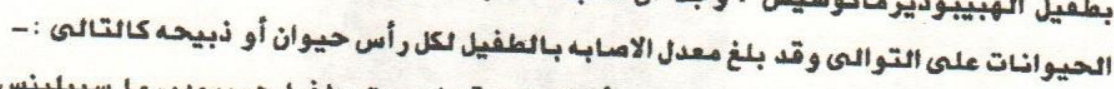

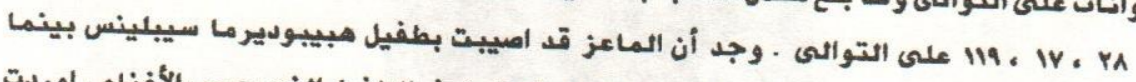

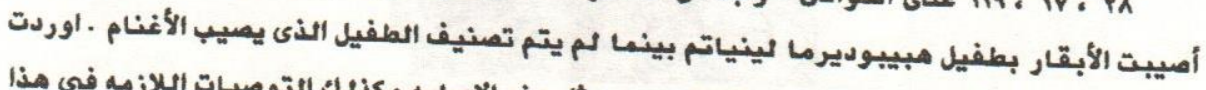
المدراسه الاضرار الاقتصاديه و الصحيه الناتجه عن مثل هذه الاصابه وكذبك التوميات التلازمه فى هذا - 1|

*: Dept. of Food Control, Fac. of Vet. Med. Cairo Univ.

Assiut Vet. Med. J. Vol. 32. No 63, October, 1994. 


\section{SUMMARY}

A total of 1880 , goat, cattle and sheep were examined for Hypodermatosis in Green Mountain-Libya. Infestation rates were $24.9 \%, 14.1 \%$ and $2.1 \%$ in that animals respectively, the mean value of recovered Hypoderma/ carcass or animal was 28,17 and 1.89 respectively. Goats were infested with H.silenus (goat warble fly), cattle with $H$. Lineatum where sheep hypodermatosis could not be identified. Differentiation between L1, L2 \& L3 of goat warble flies mentioned as well as economic losses and hazards resulted from this affections. Control and recommendations were stated.

Keywords:

Hypodermatosis, animals, meat production, Green Mountain Llbya

\section{INTRODUCTION}

Hypodermatosis is a disease of animals occasionally man. Adult flies appear during June to September and live for a short time (usually 2-7 days). Female warble flies lay their eggs on the roots of hairs of hind legs and belly of animals, hatch and penentrate subcutaneus tissues and reach the predilection sites on the back. Most of the life span of the parasites is found in the host; cattle, goat, red deer, roe deer, sometimes sheep and man (DEMPSEY; 1983).

The two main common species of Hypoderma are H.bovis and H. Lineatum and considered as parasites of cattle in many countries in Northern hemisphere including mediterranean subregions (DEMPSEY, 1983; GRACEY, 1986 and URQUHART, 1991).

Other species of Hypoderma as H.diana dose not infect cattle however inhabit red deer, roe deer and sometimes sheep. In the later the warbles have never developed fully, forming so called (bind warbles) without skin perforation (DEMPSEY 1983, URQUHART, 1991).

Concerning goats, there are three species of Hypoderma namley H.crossii (in punjab), H. aeratum (in Crete and Cyprus) and H.silenus in Central Asia. The the former two species encountered occsionally in sheep where the later in gazelle at North and Cast Africa (ZUMPT, 1965).

the larvae under skin damage adjacent flesh, described as "licked beef", followed by haemorrhagic oedema of subcutaneous tissues around the larvae termed as "butcher's jelly". The two cases necessiate local trimming from the carcass resulted in

Assiut Vet. Med. J. Vol. 32 No. 63, October 1994. 
lowering their overall value. Damage of skin give rise to inferior grades (GRACEY, 1986; URQUHART, 1991).

The number of sheep, goat and cattle, according to the official libyan authorities in 1987, was 4.356.191, 1.72.213 and 97.632 respectively. Most of these animals furnishing meat production. The local libyan breeds of sheep are Barbary, Barky and a mix of Marino and Barary. On the other hand one local breed of goat called Nowaby furnishing meat and milk production. Cattle are a mix of local Shorthorn and Italian breeds.

Our main task of work is to record the incidence of hypodermatosis (is called Abou Tagug* by libyan farmers) among animals furnishing meat production in Green Mountain region mainly goat, sheep and cattle. Our goal is also to identify the recovered hypoderma as well as differentiation between $1-2^{\text {st }}-$ and $3^{\text {rd }}$ - stage larvae of goat hypoderma. Economic losses and hazards resulted from this parasite is also aimed.

\section{MATERIAL AND METHODS}

A total number of 1502 slaughtered Nowaby goats, 85 local libyan breeds of cattle and 428 sheep were examined for the presence of Hypoderma species during routine post mortem examination at slaughter house, where cattle were examined alive in the region under investigation (Green Mountain-Libya-up to $500 \mathrm{~km}^{2}$ square and $800 \mathrm{~m}$ altitude).

Investigations were done during the period from September 1992 to September 1994. Hypoderma larvae were collected from the living cattle by manual pressure on the warbles. During post mortem examination of slaughtered goat and sheep the larvae were collected with their surrounding tissues by trimming of the affected subcutaneous tissues, transfered to the laboratory for the other investigations. The recovered Hypoderma were put directly in $70 \%$ alcohol glycerol.

Identification of Hypoderma species in goat and cattle were performed according to ZUMPT, (1965). For differentiation of first, second and third stage larvae ( $\left.\mathrm{L}_{1}, \mathrm{~L}_{2}, \mathrm{~L}_{3}\right)$ of goat warble flies, the specimens were collected at different periods, cleared in hot solution of $10 \%$ potassium hydroxide and prepared for mounting in canada balsm for the proper identification.

\section{RESULTS}

Are presented in Tables 1-3 and Fig. 1-4 \& 1-3 Plates.

Assiut Vet. Med. J. Vol. 32 No. 63, October 1994. 


\section{DISCUSSION}

It is noticed from table (1) that the incidence among goats, cattle and sheep was $24.9 \%, 14.1 \%$ and $2.1 \%$ with mean number of 28,17 and 1.89 per carcass or alive animal respectively. From the same table, it could be observed also that the incidence among 1880 animals furnishing meat production was $21 \%$ with mean value of 27.07 larvae/ animal or carcass.

Over $60 \%$ of affected goat carcases had a number of larvae ranged from 16 to 20 , while all affected mutton had a number less than 10. Among cattle, 58.33\% had 11-15 larvae/animal and the rest had a range of 1-10 larvae/animal (Table 2).

Presence of larvae subcutaneously in goats produce lesions in a form of urticaria surrounded the dead larvae or may be contaminated with pyogenic microorganisms giving rise to abscess formation. These lesions lead to thinning or poring of skin in this area, resulting in lowering the grades of skin.

The first stage larvae ( $\left.L_{1}\right)$ are present in small nodules, transversly in position with protruded posterior end externally. Skin perforation was clearly seen in case of second and third stage larvae (L2 \& L3). These L2 \& L3 were surrounded by a connective tissue capsules, opened externally, some of them exude pus.

Small fibrosed nodules at the size of pea nuts were observed at mid April till end of May in the subcutanoeus tissues on back of slaughtered goats. By incision of these nodules, black scar formation was observed and considered the print figuers of Hypoderma larvae, which dropped from their warbles.

The lesion in mutton was in the form of abscess surrounded by a hyperaemic zone and by pressure obtaining a pus and some debrises of hypoderma larvae. It was be difficult to obtain intact larvae, therefore development of warbles in sheep is incomplete. Same conclusion was ststed also by URQUHART et al. (1991).

Presence of Hypoderma in carcases necessiate local trimming of these affected parts, therefore rendered meat of low quality. Some of meat inspectors neglect some larvae during inspection in slaughter houses as this parasite is not transmissible directly to man therefore we could see some neglected larvae protruded from the subcutaneous tissue of affected goat carcases in retial markets. Due to the warbles on back of goats, the skin will loss its value not only because of pores (sometimes reach 60 pores/carcass) but also due to loss

Assiut Vet. Med. J. Vol. 32 No. 63, October 1994. 
of thickness in the affected parts. Carcass and offal losses are probably of minor significance compared with those of milk and live weight as well as hide.

Hide damage due to laceration and wounds can be also considerable. In United States, hides possising five or more warbles holes are classified as Grade 2 but hides contain numerous holes are saled for inedible by-products (GRACEY, 1986). From the achieved results in table (2) all the affected skin of goats contain more than 5 larvae/carcass truely 16 or more (i.e. holes), according to abovementioned American laws 2). of skin obtained from goat is not fit for industry (Table

First, second and third stage larvae of warbles in goats were detected only in subcutaneous tissues. This means there is no further migration internally as in case of cattle hypoderma.

The recovered hypoderma larvae from slaughtered goats were described by us with reference to some descriptions according
to ZUMPT, 1965, GRUNIN, 1962) as following:

First stage larvae ( $\left.L_{1}\right)$ :

This L1 was found in goat carcases in August, September and October, with a peak from mid August to mid September.

Macroscopic examination revealed that, the colour was creamy white, selender in shape and 10 segmented longated body had a mean size of $10 \times 2 \mathrm{~mm}$ (table 3 ).

Microscopic examination showed that the surface of the body was not provided with spines, however, on the dorsal side of the last segment (posterior end), small, brown, numerous spines were observed. Cephaloskeleton is weakly developed, not projected in the anterior end, brown in colour, with two cresentic hooks. The labial sclerits are elongated, bended and forked terminally. Concerning antierior end, there is a scattering of black spots on the first segment. The posterior pore (Fig. $1 \& 2$, plate 1 ).

Second stage larvae (L2):

These L2 were seen on goats in the period from last of September till mid of January, with a peak of incidence in October, November and December.

Macroscopic examination showed that the colour was white to yellowish alongated, obovoid in shape with anterior wider segements. The size was $6-15 \times 1.5-6 \mathrm{~mm}$. (table 3 ).

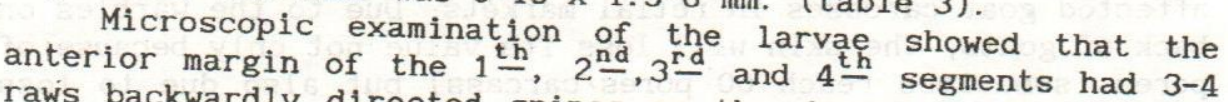
raws backwardly directed spines on the dorsal surface, while

Assiut Vet. Med. J. Vol, 32 No. 63, October 1994. 
the posterior margins of $1 \frac{\mathrm{st}}{-}, 2^{\mathrm{nd}}, 3^{\mathrm{rd}}, 4 \frac{\mathrm{th}}{-}$ and $5^{\mathrm{th}}$ segments with 5-7 raws of anteriorly directed spines. The venteral surface showed more well developed spinulation, the anterior and posterior margin of the $1^{\mathrm{st}}$ till the $8^{\mathrm{th}}$ segment had $5-8$ raws of spines. Cephaloskeleton could not be seen in intact specimens due to the thickness of the cuticle. In mounted samples, cephaloskeleton was brown in colour, without hooks, the labial sclerits were attached anteriorly. Periterms of the posterior spiracles were cresentic or kidney shape, opened posteriorly, contained numberous oral pores. The number of that pores varies from samples to other, one spiracle contain large number of pores $(18-21)$, the other contained 12-17. At the internal side of spiracles, there are small, elongated tubes which may be a traces of spiracles in the first stage larvae a9afig. 1 \& 3, plate, 2).

Third stage larvae (L3):

This stage of larvae were collected from goat carcases at mid January till mid April with a peak number in February and March. Young L3 were a white to yellowish colour, while full mature ones were brown to dark brown colour. The shape was barrel with size of $15-20 \times 7-9.5 \mathrm{~mm}$.

Microscopic examination revealed that the dorsal surface of the $2^{\text {nd }}$ till $7^{\text {th }}$ segment (anterior margin) had 1-2 raws of armatures in the form of pointed tubericles backwardly directed. The $1 \frac{\mathrm{st}}{-}$ till the 6 th segments (posterior margin) had 1-2 raws of anteriorly directed spines. On the ventral surface of the larvae, the anterior margins of all segments were armed with 1-2 raws of backwardly directed tubercules. On the same surface, the posterior margins of $2^{\text {nd }}$ till $7^{\text {th }}$ segments contained spinalation decrease in intensity from anterior to posterior (5-1) raws of spines.

Mouth dots and cephaloskeleton:

Two mouth dots could be seen from the ventral view (convex side). Spines (1-15) were present over mouth dots, arranged in two raws or two groups. These spines occured in $65 \%$ of examined $3^{\text {rd }}$ stage larvae. Cephaloskelton is present under mouth dots and more sclerotized, without hooks, its structure is similar to that of L2.

Posterior spiracles were seen from the dorsal view, C-shaped with a narrow channel, and brown to dark brown periterms, which are more sclerotized in full mature larvae. Pores were arranged in 17-19 groups, in each spiracle. Their number ranged from 150-230 in spiracle of one side and in other from 200-250 (table 3, Fig. 1 \& 3, plate 3).

Assiut Vet. Med. J. Vol. 32 No. 63, October 1994. 
From the abovementioned descriptions of the three stages of hypoderma larvae in slaughtered goats and their figures, we concluded that the hypoderma of goats is Hypoderma silenus, Bureai (see figures \& plates) sheep and cattle are not susceptible to this species of Hypoderma. Cattle were infested with Hypoderma lineatum (Fig. 4).

ZUMPT (1965) gave some descriptions on H. silenus larvae collected from gazelles in North Africa, while GRUNIN (1953 \& 1962) recorded this species from goats and sheep in Central Asia. Our results as incidence, descriptions of larval stages, pathogenesis of the parasite in goats are considered as the first record in Libya.

\section{REFERENCES}

Dempsey, J. (1983): Meat hygienest, May, June, 15.

Gracey, J. (1986): Meat hygiene, English Language Book Society Bailliere Tindall.

Grunin, K. YA. (1953): The Larvae of The Botflies of Domestic Animals of the U.S.S.R (in Russian) Operd: Fauna USSR no. 51 no. 51, 125, Moscow.

Grunin, K. YA. (1962): Botflies (Hypodermatidae) in Russian Fauna USSR, Insecta; Diptera 19, no. 4, 237.

Urquhart, G.M. A. Amouri J.L. Duncan, A.M. Dunn and F.W. Jennigs (1991): Veterinary Parasitology. Longman Scientifics and Technical.

Zumpt, F. (1965): Myiasis in Man and Animals In The Old Worled, Butterworth, London (189-242).

\section{LEGENDS}

Fig. 1: Different larval stages of $H$. silenus from left to right; First three are L3, following four: L2, the last one is L1.

Fig. 2: Posterior spircular tube (dorsal view) showing a trace of spircular tube of 1 st larval stage (Li) $\times 12$.

Fig. 3: Posterior periterms of $2^{\text {nd }}$ larval stage (L2) of $H$. silenus showing pores $\times 16$.

Fig. 4: Warbled cattle showing $3^{\text {rd }}$ larval stage (L3) of H. Lineatum; manually protruded.

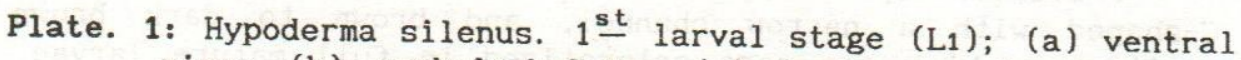
view; (b) cephaloskeleton (c) last segment with the posterior spircular tube.

Assiut Vet. Med. J. Vol. 32 No. 63, October 1994. 
Plate. 2: H. silenus. $2^{\text {nd }}$ larval stage (L2) (a) ventral view; (b) cephaloskeleton.

Plate. 3: H. silenus, 3- larval stage (L3).
(a) dorsal view,
(b) ventral view
(c) frontal view
(e) ventral view of $5^{\text {th }}$ segment
(d) posterior spiracles

Table (1): Incidence of Hypodermatosis among goat, cattle and sheep

\begin{tabular}{|l|c|c|c|c|}
\hline \multirow{2}{*}{$\begin{array}{c}\text { Type of } \\
\text { animal }\end{array}$} & \multicolumn{2}{|c|}{ Number of animal3 } & \multicolumn{2}{c|}{ Larvae recovered } \\
\cline { 2 - 5 } & Examined & incidence & No. & Mean/carcase \\
\hline \multirow{2}{*}{ Goat } & 1502 & $374(24.9 \%)$ & 10472 & 28 \\
Cattle & 85 & $12(14.1 \%)$ & 204 & 17 \\
Sheep & 428 & $9(2.1 \%)$ & 17 & 1.89 \\
Total & 1880 & $395(21.0 \%)$ & 10693 & 27.07 \\
\hline
\end{tabular}

Table (2): Distribution range of Hypodermatosis among goat, cattle and sheep

\begin{tabular}{|l|r|r|r|r|r|r|}
\hline \multirow{2}{*}{ Range } & \multicolumn{2}{|c|}{ Goat } & \multicolumn{2}{c|}{ Cattle } & \multicolumn{2}{c|}{ Sheep } \\
\cline { 2 - 6 } & No. & $\%$ & No. & $\%$ & No. & $\%$ \\
\hline $1-10$ & - & - & 5 & 41.67 & 9 & 100 \\
$11-15$ & - & - & 7 & 58.33 & - & - \\
$16-20$ & 238 & 63.63 & - & - & - & - \\
Over 20 & 136 & 36.37 & - & - & - & - \\
Tota1. & 374 & 100 & 12 & 100 & 9 & 100 \\
\hline
\end{tabular}

Hypoderma in goat is H. silenus, in cattle H. lineatum, in sheep unidentified hypoderma species.

Assiut Vet. Med. J. Vo1. 32 No. 63, October 1994. 
Table (3): Characteristic features of different stage larvae of Hypoderma silenus (goal warbie flies).

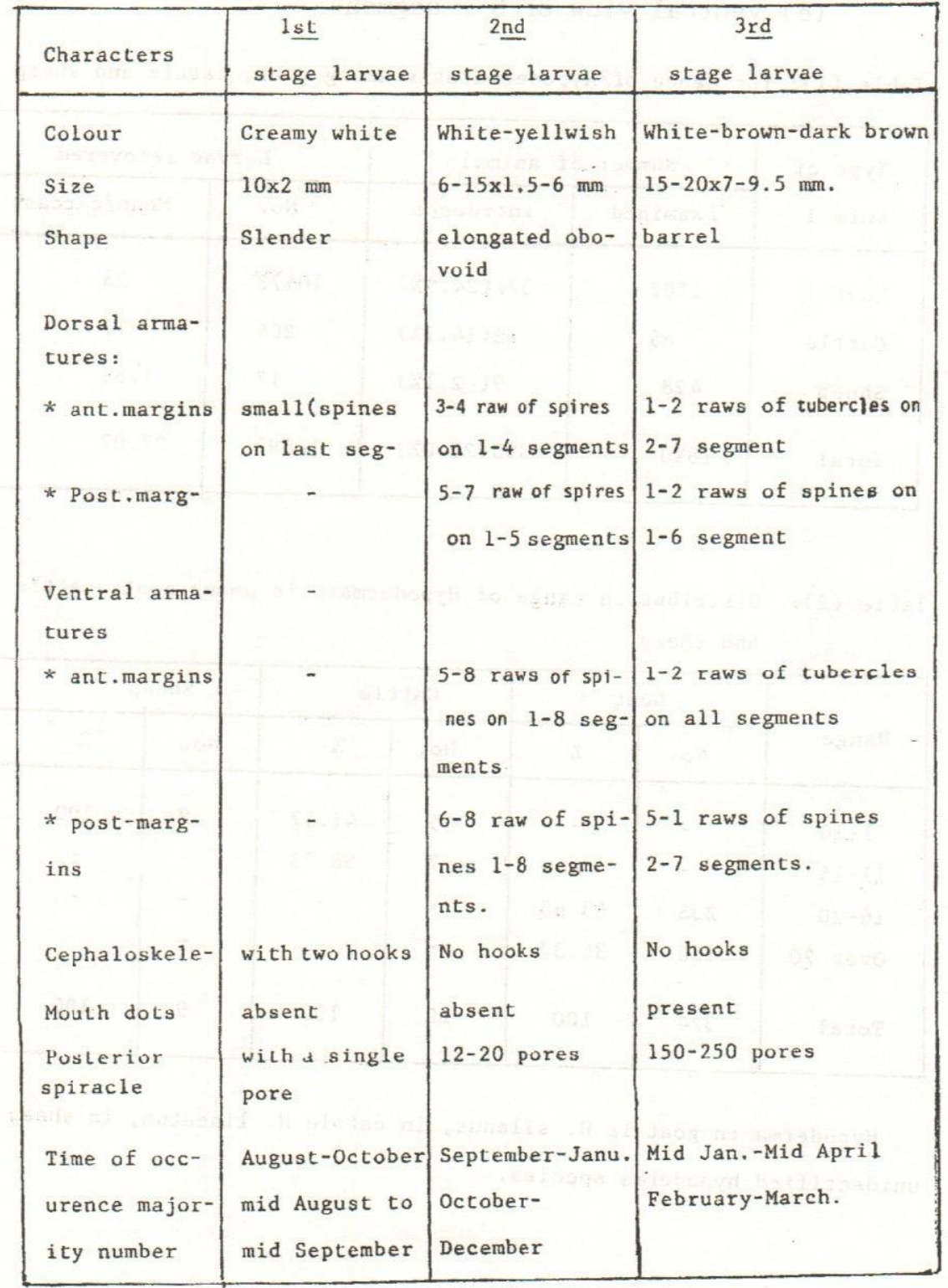

Assiut Vet. Med. J. Vol. 32 No. 63, October 1994. 
HYPODERMATOSIS, ANIMALS \& GREEN MOUNTAIN-LIBYA

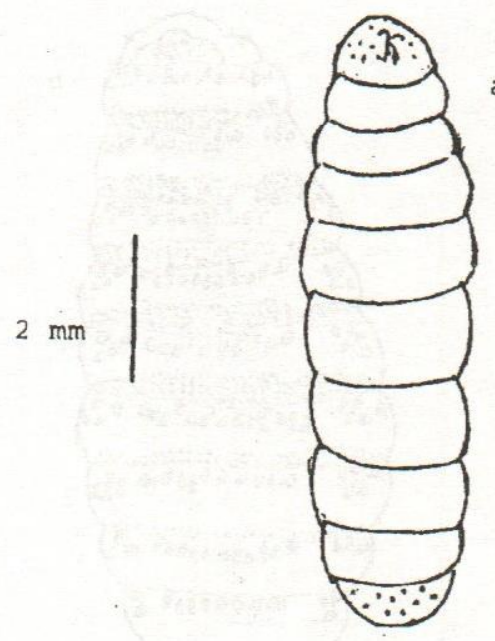

a

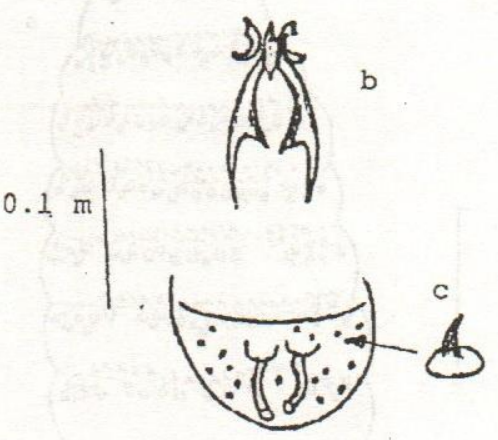

Plate 1
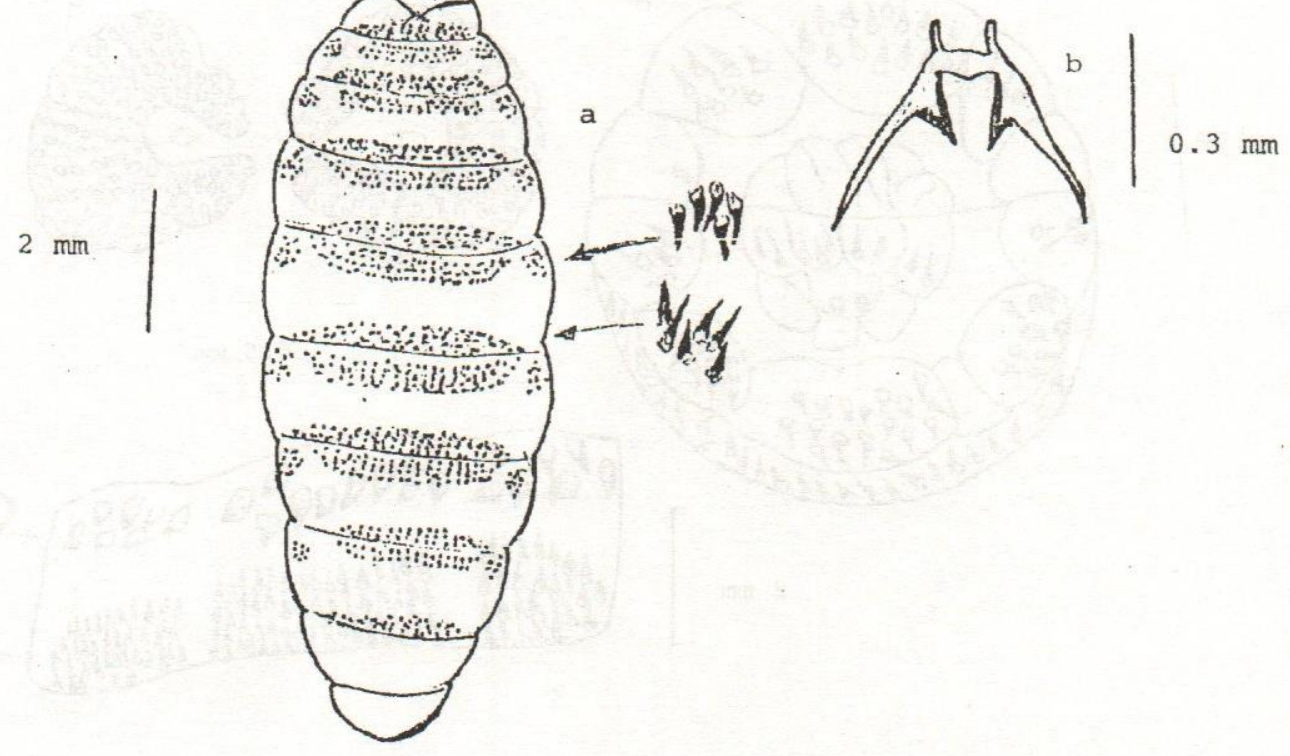

Plate 2

Assiut Vet. Med. J. Vol. 32 No. 63, October 1994.

63 

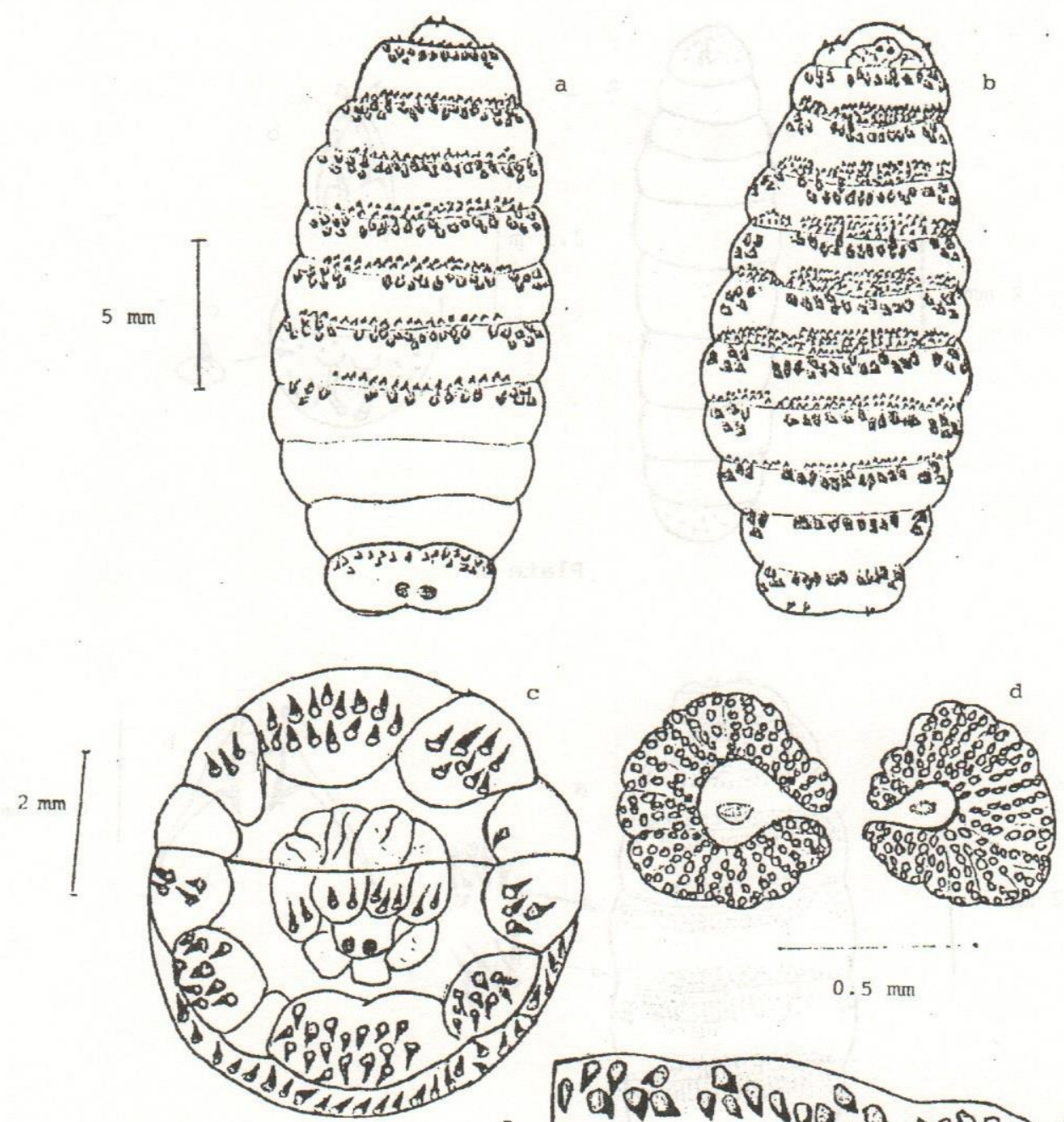

$0.5 \mathrm{~mm}$
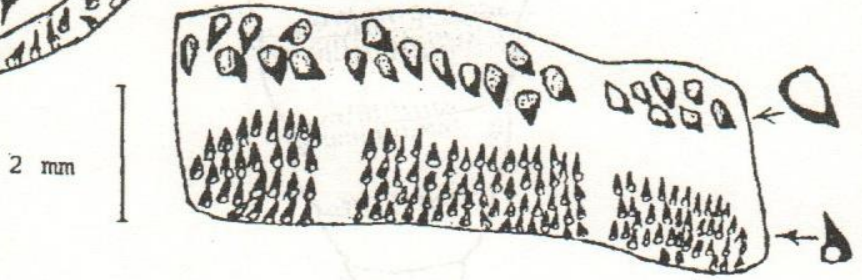

Plate 3

Assiut Vet. Med. J. Vol. 32 No. 63, October 1994. 

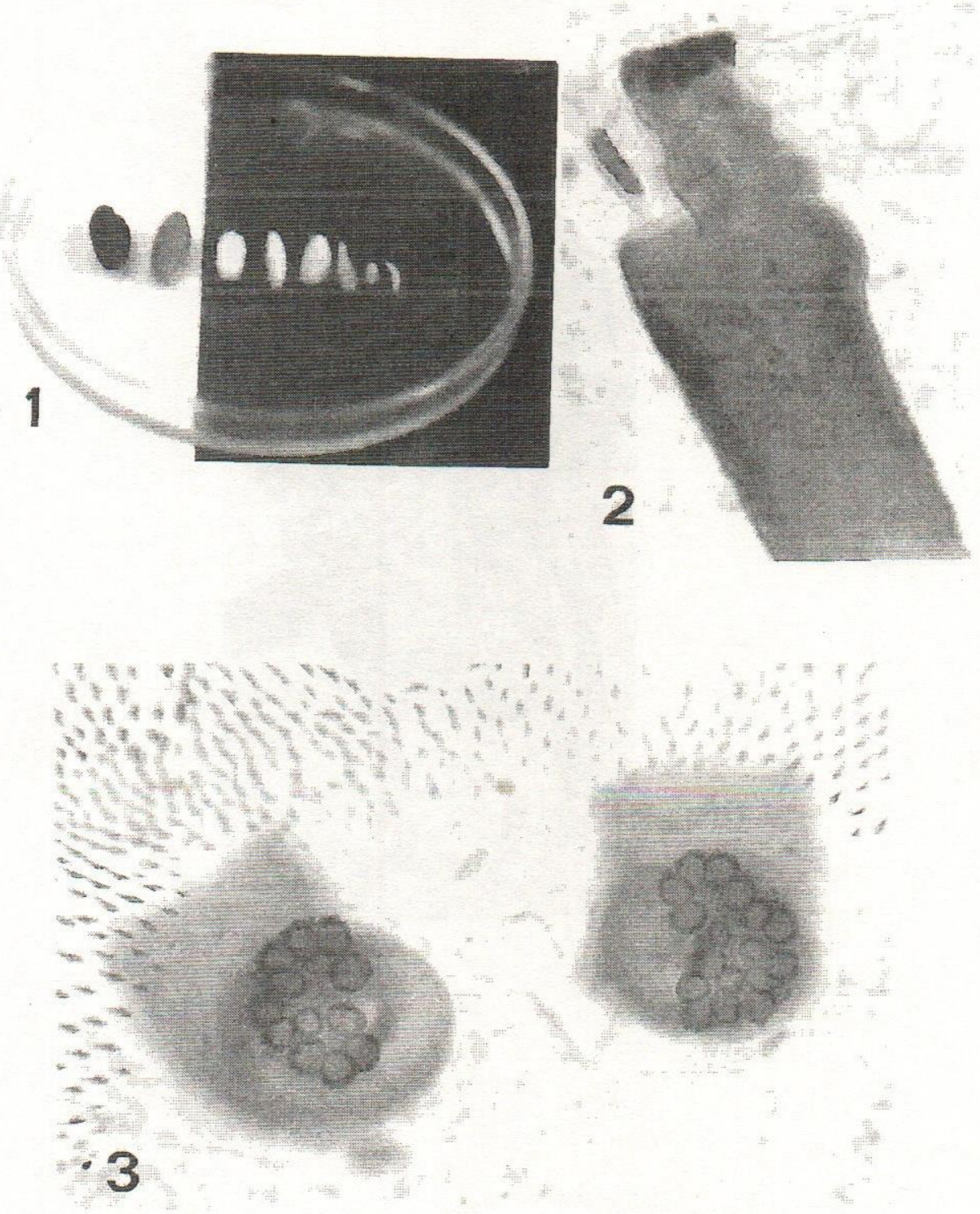

Assiut Vet. Med. J. Vol, 32 No. 63, October 1994. 


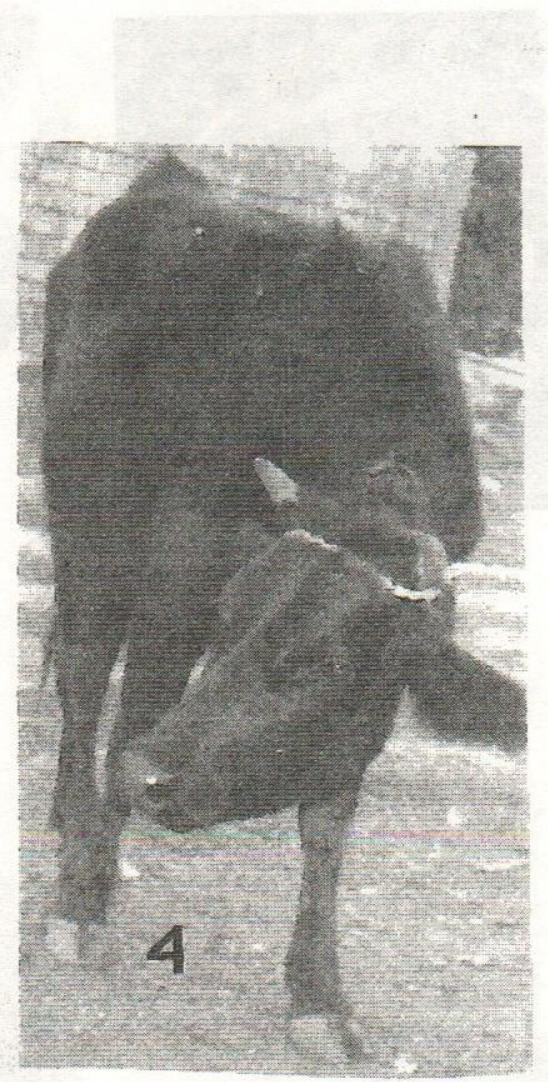

Assiut Vet. Med. J. Vol. 32 No. 63, October 1994. 